\title{
The Chinese totem of dragon and the greek myth of oedipus: a comparative psychoanalytic study
}

\author{
Huaiyu Wang ${ }^{1}$
}

Received: 30 June 2015/Revised: 29 August 2015/Accepted: 12 October 2015/

Published online: 20 November 2015

(C) Academy for International Communication of Chinese Culture and Springer-Verlag Berlin Heidelberg 2015

\begin{abstract}
By drawing upon Freud's provocative interpretation on the psychological foundation of ethical and cultural development, I hope to shed a new light on the meanings and origins of dragon worship in early China and its intriguing analogy with the Greek myth of Oedipus. As I will demonstrate, the psychological condition for the Chinese dragon worship compares well to the psychological syndrome underlying the Greek myth of Oedipus. The two aspects of the Oedipus complex, namely the father complex and repressed incest wishes, boil down to the ambivalent attitude toward the father and the tabooed sexual object. They are both present in the Chinese dragon worship. As a conclusion of my study, I will present a unified interpretation on these two aspects of the Oedipus complex in the Chinese dragon worship. At the same time, I will also make out certain distinctive features of the early Chinese solution to such psychological syndrome that are beyond universal psychoanalytic determinations.
\end{abstract}

Keywords Chinese dragon worship - Oedipus complex · Totemism · Psychoanalysis and anthropology · Freud

The dragon (long 龍) has long been a symbol of the Chinese people. The first appearances of Chinese images of dragon date back more than 5,000 years. ${ }^{1}$ These

\footnotetext{
${ }^{1}$ See for example the photo and description of a pig-dragon carved in jade of Neolithic period (c. 3000 BC) in Rawson 1996, p. 14. Following the practice of previous scholarship, I have translated the Chinese name "long" with the English word "dragon." This translation does not mean to dismiss the considerable differences between the two creatures. But given the striking similarities between these two creatures as I
}

Huaiyu Wang

huaiyu.wang@gcsu.edu

1 Department of Philosophy and Liberal Studies, Georgia College \& State University, Milledgeville, USA 
images of dragon have showed themselves on bronze sacrificial instruments and jade pendants, on robes, chairs, and beds of the kings and emperors, on different parts of temples and palace buildings, on a variety of weapons, wagons, and artworks. Although it is predominantly a sign of auspice today, the dragon has also been an omen of misfortune and disaster in early Chinese beliefs. Such double symbolic meanings of dragon reflect the enigmatic nature of this imaginary animal, whose origin is mysterious as its figure and identity are complex and capricious.

Remarkably, there have been a range of scholarly investigations into the meanings and origins of dragon based on historical, archeological, and anthological studies. However, we can find few study on the psychological origins of Chinese dragon worship and its ethical and cultural implications. In this paper, by drawing upon Freud's interpretation of the psychological foundation of all ethical and cultural development, I propose to shed a new light on the meanings and origins of the dragon worship and its intriguing analogy with the Greek myth of Oedipus. In what follows, I will recap first Freud's theory of totemism as I establish the relevancy of Freud's theory for the present investigation. After that, I will demonstrate that the Chinese dragon worship and the Greek myth of Oedipus originate in the same kind of psychological syndromes. The two aspects of the Oedipus complex, namely the father complex and repressed incest wishes-which boil down to the ambivalent attitude toward the father and tabooed incest wishes, are both present in Chinese dragon worship. As a conclusion of my study, I will demonstrate how the theory of psychoanalysis may provide a coherent interpretation of these two aspects of the psychological syndrome in Chinese dragon worship. At the same time, I will make out certain distinctive features of the ancient Chinese solution to the psychological syndrome that are beyond universal psychoanalytic determination.

\section{Freud's theory of totemism and the methodology of investigation}

In Totem and Taboo, Freud sums up the basic features of totem worship as follows: "The totems were originally only animals and were considered the ancestors of single tribes. The totem was hereditary only through the female line; it was forbidden to kill the totem (or to eat it, which under primitive conditions amounts to the same thing); members of a totem were forbidden to have sexual intercourse with each other." 2 These facts refer to three major elements of totemism: (1) taboos in relation

\footnotetext{
Footnote 1 continued

will show below, it makes good sense to regard the Chinese long as a counterpart of the dragon in Western myths and legends. I believe this translation may facilitate cross-cultural investigation on the symbolic meanings of the dragon and "long" without eclipsing their differences, which I will spell out as well.

2 Freud (1995, p. 857). These essential facts that Freud summarized almost a century ago tallies well with the current definition of totemism. In a recent article for the Encyclopcedia Britannica, for example, Prof. Josef Haekel gives the following essential characteristics of totemism: "(1) viewing the totem as a companion, relative, protector, progenitor, or helper-superhuman powers and abilities are ascribed to totems and totems are not only offered respect or occasional veneration but also can become objects of awe and fear; (2) use of special names and emblems to refer to the totem; (3) partial identification with the
} 
to the totem, such as the taboo against exogamy and the killing the totem animal; (2) the identification of tribal members with the totem animal; (3) the ambivalent attitude toward the taboo object or the action forbidden by the taboo, which is manifested for example in the co-existence of love and hate toward the totem animal that is sacrificed periodically in primitive communal feast. For Freud, there is a deep similarity between primitive totemism and the symptoms of compulsive neurotics, which are both characterized by the feeling of ambivalence. This similarity indicates a revealing analogy between the psychological syndromes underlying totemism and the Greek Myth of Oedipus. According to this analysis, "the totemic system resulted from the conditions underlying the Oedipus complex." "The totem animal is a substitute of the father and the totemic system originates in the primordial crimethe killing the primal father by the band of brothers impelled by the incest wishes towards their mother. Totemism is one of the earliest social institutions by means of which the Oedipus complexes of the primitive people are repressed. The institution of totemism stemmed from a sense of guilt for the primordial crime, which "survive for thousands of years, remaining effective in generations which could not have known anything of this deed." 4 The survival of this sense of guilt takes the form of the "infantile recurrence of totemism" and the "conscience phobia" whose sources remain unknown and unconscious. Freud makes out this unknown and unconscious source of conscience to be the Oedipus complex, viz. the repressed incest and patricide wishes. Taboo, accordingly, is "a command of conscience, the violation of which causes a terrible sense of guilt which is as self-evident as its origin is unknown." In conclusion, "the beginning of religion, ethics, society, and art meet in the Oedipus complex." 6 The overcoming of this primitive human condition through the formation of ego-ideal and conscience prohibitions answer to "everything that is expected of the higher nature of man.",

Admittedly, anthropologists have been hesitant to recognize Freud's conclusions in Totem and Taboo. ${ }^{8}$ Freud's theory does not even appear in Levi-Strauss's review of scholarly interpretations of totemism. Levi-Strauss dismisses Freud's hypothesis in passing based on his thesis on illusory nature of totemism. The long silence in the field of totemism after Lévi-Strauss seems to bear out a wide skepticism toward the "phenomena" of totemism itself. But the case of totemism is far from closed. As Joseph Haekel concludes in his article for the Encyclopedia Britannica, "it seems fair to many authorities to ask whether it is possible to dispose of totemism simply as an illusion, whether the very abstract structural interpretation of the facts is actually legitimate. To those who question the position, it seems clear that even

\footnotetext{
Footnote 2 continued

totem or symbolic assimilation to it; (4) prohibition against killing, eating, or touching the totem, even as a rule to shun it; and (5) totemistic rituals." ("Totemism" 2015).

3 Freud, Ibid., p. 876.

4 Ibid. p. 895.

5 Ibid., p. 827-28.

6 Freud (1995, p. 895).

7 Freud (1960, p. 33).

${ }^{8}$ For a summary of the criticism of Freud's Totem and Taboo, see Wallace, IV (1983, Chap. 3).
} 
though all totemistic forms of expression can hardly be seen under one common denominator, reality cannot be totally denied to totemism." ${ }^{\text {"9 }}$ Edwin Wallace has also pointed out that while anthropologists direct much of the negative criticism against Freud's explanation of totemism, "his ideas on the incest taboo, on spirits as projections, on magic as wish fulfillment and omnipotence of thoughts, and on ambivalence toward the dead have been favorably received."10

As I see it, the anthropological discourse on totemism is compromised by a misplaced focus on the "reality of totemism." The theory of totemism can only be "verified" by archeological and anthropological discoveries and evidence about the "realities" of primitive societies. However, in the eyes of modern Western researchers, primitive beliefs such as the superstitions concerning the holiness of certain animals are nothing but fictions or illusions. It is thus doubtable to what kind of reality should the theory of totemism correspond. To the "reality" of primitive fictions and illusions, which are characterized precisely by their lack of reality? Thus, there seems to be no way to "verify" the psychoanalytical narrative of the primitive beliefs. The theory of totemism may be essentially "unverifiable." Even Levi-Strauss acknowledges that "we do not know, and shall never know, anything about the first origin of beliefs and customs the roots of which plunge into a distant past." 11

Nevertheless, we cannot dismiss the theory of totemism simply for the so-called lack of "hard" historical or anthropological "verification." Nor should we equate a narrative of an illusion and its origin with the "illusion" itself. After all, what is unverifiable "scientifically" is not necessarily "meaningless." Rather, the true meaning of a theory may well consist in a distinctive vision that promises to bring the complicated phenomena of the primitive myths and beliefs to a possible unity. It is here that contemporary science of anthropology meets its limits. The anthropologists have not done justice to Freud's theory of totemism because they have not put themselves in the right relation to Freud's discoveries. The question is not whether or not Freud's conclusions in Totem and Taboo provide any verifiable or useful information about the primitive people that may help anthropological studies. Rather, the question is how the revelation of the Oedipus complex as the common destiny of human existence ever since the earliest ages may redefine and restructure the anthropological project as a whole. When anthropologists confine their research within the procedures of "scientific verification," they have to leave the historical origin of the anthropological phenomena unthought. This is the very limitation of the prevalent anthropological methodologies, such as functionalism and structuralism. As Piddington confesses, "the adoption of the functional method necessarily rules out the majority of problems of origin, not because they are unimportant, but because it is impossible to study them scientifically." 12

Here, I am not in a position to evaluate the universal and scientific validity of Freud's theories about totemism and the Oedipus complex as the foundation of

\footnotetext{
9 "Totemism" (2015).

${ }^{10}$ Wallace, IV, p. 169.

${ }^{11}$ Lévi-Strauss (1963, p.70).

12 Piddington (1952, p. 27).
} 
human culture and ethical consciousness. My purpose is to demonstrate how the psychoanalytic theory may bring a new insight into the enigmas surrounding the phenomena of dragon worship in early China. As I will show, the underlying psychological conditions of Chinese dragon worship compares well to those of the Greek myth of Oedipus. They both involve the ambivalent attitudes toward the father and tabooed sexual desires, as well as the primal anxiety about the helplessness of primordial human situation. Moreover, it is important to note that my comparative study does not presume the discoveries of psychoanalysis as a universal standard for the evaluation and interpretation of the Chinese cultural practice. For me, Freud's theory functions as a valuable heuristic to explore the still unknown origin of Chinese dragon worship. Accordingly, I will give due attention to both agreement and disagreement between the universal scheme of human civilization as projected by Freud and the particular path of Chinese cultural development.

My investigation of the analogy between the myths of Chinese dragon and Greek Oedipus comprises three parts: (1) The demonstration of the relation between dragon worship and the psychological syndrome of father complex; (2) The revelation of dragon images as symbolic expressions of sexual and incest wishes; (3) A coherent interpretation on the psychological, ethical, and cultural implications of dragon worship in comparison with those implications of the Oedipal myth.

\section{The dragon and the father complex}

In this section, I will demonstrate the relationship between the dragon and the father complex in two steps. First, I will show that early Chinese people had ambivalent attitudes toward the dragon and the father at the same time. Second, I will establish the dragon as an early Chinese symbol for the father and the king.

\section{The ambivalent attitudes toward the dragon and the father}

Freud claims that "the relation of the child to animals has much in common with that of primitive man." 13 There are two common traits for the animal phobia of the child and the totemism of primitive man: "the complete identification with the totem animal, and the ambivalent affective attitudes towards it." 14 The ambivalence of emotions, namely the unconscious hostility hidden behind the tender love, "exists in almost all cases of intensive emotional allegiance to a particular person." 15 As a fundamental phenomenon of our emotion life, this ambivalence was originally "acquired by mankind from the father complex," 16 one essential aspect of the Oedipus complex. Hence, we can identify the animal in both primitive totemism and neurotic phobia of the child as the substitute for the father. The animal phobia of a

\footnotetext{
${ }^{13}$ Freud, (1995, p. 872).

14 Ibid., p. 876.

15 Ibid., p. 822.

16 Ibid., p. 895.
} 
child originates in the ambivalent attitude towards the father. The child can only relieve himself "of this ambivalent conflict by displacing his hostile and anxious feelings upon a substitute for the father." ${ }^{17}$ Likewise, "the totem animal is really a substitute for the father, and this really explains the contradiction that it is usually forbidden to kill the totem animal, that the killing of it results in a holiday and that the animal is killed and yet mourned. The ambivalent emotional attitude which today still marks the father complex in our children and so often continues into adult life also extended to the father substitute of the totem animal." 18 As the substitute for the father, the totem animal was also the precursor of earliest religious deities. In primitive sacrifices, the god maintains a close relation to the holy animal. While the totem was the first representative of the father, the god, which is "nothing less than an exalted father," can be taken as a later substitute in which "the father regained his human form."19

In what follows, I will demonstrate first that early Chinese people held ambivalent feelings toward both the dragon and the father. At the same time, dragon was also a symbol of the father. These two basic evidences substantiate that the dragon is a substitute for the father-a symbol upon which the ambivalent feelings were displaced. Thus, the comparison between Chinese dragon worship and the Greek myth of Oedipus will lend us a unique insight into the psychological origins of various early Chinese cultural and spiritual practices involving the images of dragon.

\section{Ambivalent feelings towards the dragon}

Early Chinese people held ambivalent attitudes toward the dragon. We can find the best evidence for such ambivalent feelings in the double nature of the dragon. Early Chinese people regarded the dragon at once as a sign of auspice and an omen of disaster. Let us look into these two natures of the dragon respectively.

The dragon as a sign of auspice As Okakura points out, the dragon in the East "is not the gruesome monster of mediaeval imagination, but the genius of strength and goodness. He is the spirit of change, therefore of life itself." ${ }^{, 20}$ Elliot Smith indicates that while in the West the dragon is usually a "power of evil," "in the far East he is equally emphatically a symbol of beneficence." 21 Today, most Chinese hold the dragon as an auspicious animal. This presumption has a long history and originates probably in the early Chinese beliefs. Contemporary scholars have few doubts about the auspicious nature of the dragon in ancient China. There is plenty of evidence in ancient Chinese literature and archeological findings to support this thesis. Here it suffices to allude to a couple of most conspicuous sources.

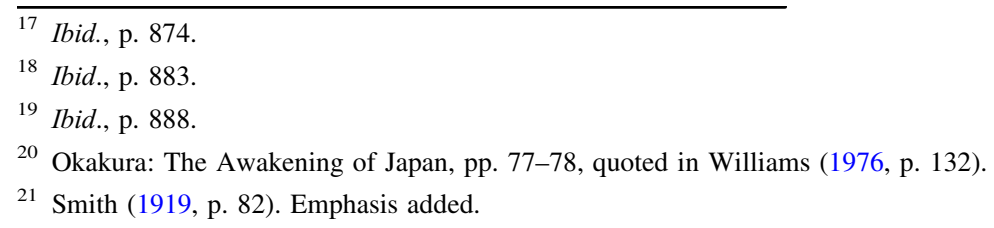


First, the presence of the image of dragon on a wide range of ancient Chinese articles and clothes attests to its auspicious nature. Insofar as textual evidence is concerned, we have a clear statement in the Book of Ritual that depicts the images of dragon on the robe of the king as a sign of nobility. ${ }^{22}$ As Prof. Ji Chengming puts it, ancient Chinese carved and drew the images of dragon on their clothes and daily instruments "for the sake of seeking auspices, taking dragon as an auspicious sign." 23 Accounts in a wide range of ancient Chinese texts confirm the dragon as an auspicious sign, indicating something fortunate. De Visser, among others, has pointed out rightly that "the birth of great sages and Emperors was preceded by the appearance of dragons and phoenixes." 24

The dragon as a demonic animal Few modern scholars have delved into the fact that the Chinese dragon was also a demonic and monstrous creature. Apparently, the popular beliefs in the auspicious nature of the dragon has overshadowed the hidden fears about this mysterious creature. But evidence is not wanting for the demonic nature of the dragon. The descriptions of the dragon as a monstrous creature, though eclipsed by the prevalent accounts of its auspicious nature, are widely present in ancient Chinese literature. De Visser enumerates a dozen instances in which dragons are taken as "bad omens" for ancient Chinese. ${ }^{25}$ Here, it is worthwhile to recount a few supportive documents. Wang Chong's Lun Heng records a demonic yellow dragon encountered by the early sage king $\mathrm{Yu}$ 禹: “Once $\mathrm{Yu}$ was riding on a river to the south. A yellow dragon took the boat on its back and the people in the boat were all frightened. Yu laughed and said: 'I receive the ordinance from heaven and try my best to benefit the people. For me, life is an expedition of which death is the destination. What can disturb me? I regard the dragon as a dragon-fly.' The dragon then fled away." 26 Han Fei Zi, likewise, calls attention to the inverted scales of the dragon and warns that whoever touches these scales will be killed by the dragon. ${ }^{27}$ The History of Han records a story about the customs of the people of Yue 越, who cut their hairs and cover their bodies with tattoos of the dragon in order to avoid the harm by the dragons in water. ${ }^{28}$ There are a couple of different versions of the same story as recorded for example by the Shuo Yuan. According to Wen Yiduo, this story must have come from the ancient texts of pre-Qin period. ${ }^{29}$ Hence, the customs of the Yue people and their fear of the dragon may well date back to a very early age.

In the West, the dragon has long been a monstrous animal representing the "power of evil." The comparison of the legends and images of the dragon in the ancient world indicate a common origin of the dragon-myth. Elliot Smith argues

\footnotetext{
22 The Book of Ritual, “Liqi禮器, ” “禮有以文為貴者. 天子龍衷.” All translation of Chinese texts are mine unless otherwise noted.

${ }^{23} \mathrm{Ji}(2002$, p. 179).

${ }^{24}$ De Visser (1913., p. 43). Cf. Tu (1967, p. 141).

25 De Visser, Ibid., pp. 45-55.

${ }^{26}$ Wang (1965, Chapter Yi Xu異虛, Cf. Tu Erwei, p. 142).

27 Hanfeizi (1965), “Shuo Nan説難."

${ }^{28}$ Ban (1965), "Dilizhit地理志".

${ }^{29}$ Wen (2001a, b, p. 104).
} 
that "an association of anatomical features of so unnatural and arbitrary a nature can only mean that all dragons are the progeny of the same ultimate ancestors... it is not merely a case of structural or anatomical similarity, but also of physiological identity, that clinches the proof of the derivation of this fantastic brood from the same parents." 30 This hypothesis about the common origin of the Eastern and Western dragons is credible. Considering the exclusively demonic nature of the dragon in the West, it is logical to assume that the dragon as a demonic monster is earlier than the dragon as a beneficent creature, which may well be a later development. ${ }^{31}$ Even in the East, indeed, "the dragon's reputation is not always blameless. For it figures in some disreputable incidents and does not escape the sort of punishment that tradition metes out to his European cousins." 32

Remarkably, it has not been easy for contemporary (Chinese) scholars to recognize the demonic nature of the dragon and the ambivalent feelings of early Chinese people. For many, the double nature of the dragon remains a puzzling problem. For example, Wen Yiduo regards it an enigma that the people of Yue, while fearful of the dragon, can still take the dragon as the auspicious totem representing their ancestors. ${ }^{33}$ In my view, Freud's theory of ambivalence and a comparative study with the Greek myth of Oedipus may lend us a unique insight into the double nature of the dragon and bring a coherent interpretation on the complex relations between the dragon symbol and the primal father figure.

\section{Ambivalent feelings towards the father}

Like the double nature of the dragon, the ambivalent feelings towards the father are seldom recognized, despite much solid evidence in ancient Chinese literature. There is a constant resistance to the idea of hostility towards the father-a resistance informed by a common faith in the prevalent loving relationships between the father and the son. Admittedly, these hostile feelings are seldom expressed straightforwardly; they remain unconscious for the most part. Thus, the proof of their presence requires certain tactics. In order to demonstrate the ambivalent feelings, it is particularly relevant to resort to the psychoanalytic clarification on the meanings of taboos. According to Freud, the ambivalent attitudes towards both the totem animal and the father figure in the ambivalent feelings toward taboos in primitive totemism. "Taboo is a very primitive prohibition imposed from without (by an authority) and directed against the strongest desires of man. The desire to violate it continues in the

\footnotetext{
30 Smith (1919, p. 81). Smith summaries the similarities of the dragons around the world as follow: "Although in the different localities a great number of most varied ingredients enter into its composition, in most places where the dragon occurs the substratum of its anatomy consists of a serpent or a crocodile, usually with the scales of a fish for covering, and the feet and wings, and sometimes also the head, of an eagle, falcon, or hawk, and the forelimbs and sometimes the head of a lion.... Wherever dragon is found, it displays a special partiality for water. It controls the rivers or seas, dwells in pools or wells, or in the clouds on the tops of mountains, regulates the tides, the flow of streams, or the rainfall, and is associated with thunder and lightning" (Smith, pp. 81-82).

31 Cf. Yuan (2003, p. 11). Yuan elaborates the transformation of the image of the Western Queen from a demonic and beastly creature to auspicious goddess with insurmountable beauty.

32 Smith (1919, p. 83).

33 Wen (2001a, b, p. 105).
} 
unconscious; persons who obey the taboo have an ambivalent feeling toward what is affected by the taboo." 34 In early Chinese societies, there were a range of taboos concerning the father and the king, as well as sophisticated rituals and customs of ancestor worship. Based on the discoveries of psychoanalysis, we can discern the underlying psychology of the institution of taboos and the customs of ancestor worship as the co-existence of love and hate toward the father.

Love of father: ancestor worship The practices of ancestor worship of ancient Chinese people are well known. The scale and sophistication of Chinese ancestral cult are remarkable compared with other early civilizations. In the Shang dynasty, ancestor worship was institutionalized systematically as a significant religious and national event. David N. Keightley asserts that the cult of ancestors in late Shang dynasty "involved not mere venerations or commemoration, but actual worship." 35 Prof. Li Chi describes the civilization of Shang dynasty as "a theocratic religion dominated by excessive devotion to ancestor worship." 36 D. Howard Smith elaborates further the relation between the ancestors and $D i$ or $T i$ 帝, the god or the divine king: "The deified ancestors of the Shang were known as Ti. When a ruler died he became a $T i$, associated on high with the first ancestor-spirit who was regarded as the supreme $T i$. A study of this character as it is used in the oracle bone inscriptions suggests that this founder ancestor of the Shang dynasty was thought of as a supreme god, dwelling on high." ${ }^{37}$ With the ancestors worshiped as the primal father, it is clear that both the god and the king, who was often named as the son of the god or heaven, represented the father figure. The practices of ancestor worship reflect a deified love or cult of the father. This tender love toward the father and the king is epitomized in the concept of xiao 孝—usually translated as "filial piety." The early Chinese practices of xiao comprise both the respect and good treatment of the living father (parents) and the long-lasting mourning and remembrance after their death. The concept of xiao plays an important role for early Chinese people. It embodies a high degree of love toward the father (parents) in ancient Chinese society.

Taboos and the Unconscious Hostility toward the Father There were a complex system of taboos and prohibitions concerning the father and the king in ancient Chinese societies. This system of taboos has a long history. It originates in the customs of early Chinese people. Ancient Chinese call these prohibitions "jinji (禁忌)." Many ancient and contemporary Chinese scholars have endeavored to rationalize these prohibitions by attributing their origins to the love of the father or the king. But the etymologies of the words $j i n$ and $j i$ betray the presence of feelings of hostility and even demonic fears. The word jin 禁, which is usually understood as "to forbid," carries a multiple of meanings. The Encyclopedic Dictionary of the Chinese Language enumerates the following meanings of jin: "prohibition, law, the

\footnotetext{
${ }^{34}$ Freud 1995, p. 802.

35 Keightley (2004, p. 11).

${ }^{36}$ Li Chi, The Beginnings of Chinese Civilisation, Seattle, 1957, p. 20, quoted in Smith 1968, p. 2.

${ }^{37}$ Smith (1968, p. 5). Cf. Guo (2000a, b, pp. 315-316).
} 
secret or mystical, the dwelling place of the king, the prison, the container of the wine, the demonic power." It is also used as a verb with the senses of "to prohibit, to hold, to preside over, to be cautious, to forbear, to order or control." 38 The Shuowen defines the original meaning of jin as "the prohibition ( $j i$ 忌) about the auspicious and the ominous." $39 \mathrm{Ji}$ 忌, which defines the word jin, carries not only the sense of "to prohibit," but also the sense of "to hate, to resent, to fear, to envy, to avoid, etc.," or the feeling or the objects of "hatred, resentment, fear, dread, envy or evasion." The most original meaning of $j i$, according to the Shuowen, is "to hate and resent." 40

The etymologies of jin and $j i$ reveal that the origins of taboos and prohibitions are none other than the feelings of hatred and dread. The objects associated with the king or the father are prohibited because they are things that one fears and avoids on one hand, but envies on the other. The dwelling place of the king, for example, is a privileged place of "envy" that the common people have to "avoid." It is a "mystical" place guarded by the taboos-by the laws that prevent the common people from transgressing the privilege of the king. The common people need to "forbear" and "be cautious" about these taboos because there are demonic powers" accompanying the prohibited objects. Thus, when the state is able to "hold" these taboos as laws, the king is said to "preside over" the state with proper "order or control" of the mysterious power. In particular, the most original meaning of $j i$ as hatred and resentment discloses ancient Chinese awareness of the kind of emotions underlying such taboos. They were the feelings of "hatred and resentment," though such feelings remain mostly in the unconscious.

Apart from the dwelling place of the king, there are a variety of other taboos about the father and the king, especially with regard to their dead bodies. These prohibitions are featured in the rules of burial, the regulations of mourning activities, the obligation to avoid the names of the father and the king in speech and writing, and so on. For example, the body of the king has long been a tabooed object that one should avoid as far as possible. A common saying in Chinese compares the duty of accompanying the king to the danger of accompanying a tiger. The Book of Ritual stipulates that when looking at the king-the son of heaven, "one should not look higher than his collar or lower than his waist-belt." ${ }^{41}$ Presumably, such sight taboos must have stemmed from the primitive superstition about the so-called mana power of the king - a mysterious power that is passed down and shared by government officials as well. In his Popular Taboos in China, Ren Cheng describes a common theatrical scene in ancient China in which people of humble origins dare not look at even the lowest rank government officers at a court without first being pardoned for their "crimes" of such looking. ${ }^{42}$

As I see it, these regulations and prohibitions stem from the early Chinese taboos about the divine power of the kingly father. Now the most remarkable of these

\footnotetext{
${ }^{38}$ Lin and Gao (1985, vol. 6, pp. 1457-1458).

39 Shuowen 説文, quoted in Lin and Ming (1985, vol. 6, p. 1457).

40 Shuowen, quoted in Lin and Ming (1985, vol. 4, pp. 1717-1718).

${ }^{41}$ The Book of Ritual, “Quli 曲禮,”“天子視不上於袷, 不下於帶; 國君, 綏視; 大夫, 衡視; 士視五步。” Cf. Ren (2004, p. 36).

${ }^{42}$ Ren Cheng, p. 36.
} 
taboos involve the names of the father and the king. According to the Confucian classics, the practice of avoiding the names of the gods and the dead king was first institutionalized in Zhou dynasty. It was soon extended so that one should not mention the father's and the king's (first) names even when they were still alive. ${ }^{43}$ When a king or monarch was dead, a special title would be endowed and used in the burial and sacrificial ceremonies and the official records afterwards. When the king and the father were still alive, one should never call them by their names but only by their titles. The characters in a king's name were forbidden to use for the whole nation. By the same token, sons and daughters would make every effort to avoid the characters in their father's name in writing and speech. Even the renowned historian Sima Qian has found it obligatory to submit to this taboo at the cost of historical veracity. In his masterpiece Shiji, Sima changes the names of historical figures such as “Zhao Tan 趙談” and “Li Tan 李談” to “Zhao Tong 趙同” and “Li Tong 李同” simply for the sake of avoiding using the character “tan 談," which was his father's first name. ${ }^{44}$

In light of the analysis above, the motives of avoiding the name of the father and the king, like other social taboos about the father figure, have much to do with the feeling of fear. This feeling of fear is well illustrated by the contemporary Chinese Erlunchun 鄂倫春 ethnic group who believe "the mentioning of the names of the ancestors is a disrespect, which will irritate the ancestors and incur disasters." 45

\section{The dragon as the symbol of the father}

According to the discoveries of psychoanalysis, the hostile feelings ensconced in the unconscious may find their satisfaction with the death of the father and the king. Such unconscious feelings of satisfaction would incur a serious sense of guilt that is displaced through the mechanism of projection. As Freud puts it, "The survivor will deny that he has ever entertained hostile impulses toward the beloved dead; but now the soul of the deceased entertains them and will try to give vent to them during the entire period of mourning. In spite of the successful defence through projection, the punitive and remorseful character of this emotional reaction manifests itself in being afraid, in self-imposed renunciations and in subjection to restrictions which are partly disguised as protective measures against the hostile demon." 46 The taboo about the dead can be traced back to the "fear of the soul of the dead after it has turned into a demon." 47 Presumably, in order to sustain a purely loving relationship with the dead, the unconscious hostile feelings are displaced and projected toward certain demonic figures. We can identify a range of such demonic figures. But the dragon is certainly a primary substitute for the demonic soul of kingly father. As the primary substitutes for the father, the totem of dragon becomes an easy target

\footnotetext{
43 See Ren Cheng, p. 322.

44 Ibid., p. 322-223.

45 Ibid., p. 322.

46 Freud 1995, p. 822.

47 Ibid., p. 823.
} 
against which the fear of the dead, in the form of the fear of the demon is displaced and projected.

Based on the ambivalent feelings towards the father and the double nature of the dragon I demonstrated above, it has become probable that the underlying psychology of the dragon worship is the father complex that is also present in the Greek myth of Oedipus. In what follows, I will substantiate further that for early Chinese people, the dragon is a substitute for the father-a symbol upon which the hostile feelings toward the father are displaced. In addition to their ambivalent feelings towards both the father and the king, early Chinese people also identify the dragon with the father and the king. This is manifested in a number of early legends and literatures.

Elliot Smith remarks that the dragon in the East was originally "the personification of water, and was identified with kings and gods."48 The Book of Changes, for example, explains the meaning of the hexagram "Zhen 震" as the dragon and the thunder. It asserts that the divine king ( $d i$ 帝) originates in the hexagram "Zhen."49 Wang Chong alludes to this identification of the dragon with the thunder also in his Lung Heng. ${ }^{50}$ Remarkably, in the Greek mythology, Zeus- the father (i.e., the ruler and protector) of both gods and men, was also regarded as the sender of thunder and lightning, rain, and winds. It seems that thunder and lightning are symbols of the demon in both ancient Greece and China. The thunder has clearly the double characters of reifying heavenly punishment and presaging propitious rains at the same time. Presumably, the association between the dragon and the thunder in The Book of Changes bear out the combination of demonic and auspicious natures in the divine king. This corresponds well with the double natures of the dragon as a symbol of the deified ancestor-the primal father.

The belief that the kings are dragons is widely present in ancient Chinese texts. De Visser relates a number of ancient Chinese legends that identify the ancient kings such as Huang Di 黄帝and Shun 舜 as dragons. ${ }^{51}$ Sima Qian's History/Shiji records a story that features Qinshihuang 秦始皇, the first emperor of the Qin dynasty, as an "ancestral dragon." 52 Moreover, the images of dragon on the dwelling places and daily utensils of the kings and emperors in the ancient China bear out also the ancient Chinese conception of the kings and emperors as dragons.

Perhaps the most convincing evidence consists in the legends that attribute the birth and conception of the great kings to the influences of dragons. Sima Qian's Shiji contains such a legend about the birth of Liu Bang 劉邦, the first emperor of the Han dynasty. The mother of Liu Bang "once slept beside a big lake and dreamed of encountering a god. During that time, it became dark and gloomy with thunders rumbling and lightning flashing. Liu Bang's father saw a couple of dragons entwined with each other having intercourse above her. Then she became pregnant

\footnotetext{
48 Smith (1919, p. vii).

49 The Book of Changes 1965, Chapter Shuo Gua說卦,, “帝出乎震 震為雷為龍.”

${ }^{50}$ Wang (1965), Chapter Longxu 龍虛: “The dragon and the thunder are the same kind and they elicit each other when affected, 雷籠同類, 感氣相致.”

51 De Visser., p. 122-126.

52 Sima (1965), Biography of Qin Shi-Huang 秦始皇本紀.
} 
and gave birth to Liu Bang." 53 The early Chinese mythology Shanhaijing relates a similar story about the conception of the ancient king $\mathrm{Fu} \mathrm{Xi}$ 伏羲 whose image is often associated with the dragon: "A big footprint came out of the Lake of Thunder. Hua Xu trod on it and then gave birth to Fu Xi." 54

It is revealing to compare these legends with the beliefs of the primitives in Australia and Melanesia. As James Frazer reports in his Totemism and Exogamy, "women become impregnated when a spirit of an animal or a spiritual fruit enters into their wombs. Since the children therefore participate in the nature of the animal or plant, these plants or animals take on significance. These ideas were hereditary and resulted in the beginning of totem clans derived from a particular natural creature." ${ }^{, 5}$ In light of psychoanalysis, the underlying motive of these legends is none other than the attempts to identify the spiritual powers in the specific animals and plants as responsible for the birth of the human figures. There is thus little doubt that the Chinese dragon symbolizes the spiritual power essential for the birth of the great kings. The "thunder" that appears in both stories above, first as the real thunder and second as the name of the lake, implies the presence of the dragon. The dragon is the symbol of the deified father. This symbolic meaning of the dragon is evidenced again by another story about the conception of Houji 后稷, the first king of the people of Zhou. This conception is believed to have taken place after the legendary mother trod upon the footprint of the divine king, or the king of heaven (天帝 tiandi). ${ }^{56}$ Presumably, both the heavenly king and the dragon represent the primal father. Accordingly, the ancient Chinese designate the kings as the "sons of heaven," who were believed to have inherited the special spiritual or demonic powers of the dragons and the gods.

\section{The dragon and the incest wish}

The double nature of the dragon, the ambivalent feelings toward the dragon and the father, and the identification of dragon as a symbol for the father all substantiate the father complex as the underlying psychological syndrome of dragon worship. In this section, I propose to demonstrate the other dimension of the Oedipus complex in early Chinese dragon worship: the sexual implications of the dragon and its relation to primitive incest wishes. In what follows, I will examine first early Chinese sexual taboos and reveal the ambivalent attitudes toward incest activities. After that, I will clarify the sexual implications of "dragon couples" that are widely represented in

\footnotetext{
53 Sima Qian 1965, Biography of Liu Bang 劉邦本紀.

54 Shanhai Jing 山海經, Chapter Hai Nei Dong Jing 海内東經, quoted in Wen (2001b, p. 148).

55 Frazer, Totemism and Exogamy, quoted and elaborated in "Totemism" 2015: "Basing his view on research done among primitives in Australia and Melanesia, Frazer saw the origin of totemism as one possibility in the primitive interpretation of the conception and birth of children ("conceptionalism"). According to this primitive idea, women become impregnated when a spirit of an animal or a spiritual fruit enters into their wombs. Since the children therefore participate in the nature of the animal or plant, these plants or animals take on significance. These ideas were hereditary and resulted in the beginning of totem clans derived from a particular natural creature."

56 There are a number of different versions of this story, see Wen (2001b, p. 148).
} 
ancient Chinese legends, bronze sacrificial instruments, paintings, sculptures and other artworks.

\section{Sexual taboos and ambivalence toward Incest}

The ancient Chinese sexual taboos are as complex as taboos concerning the father and the king. In light of psychoanalysis, the presence of these taboos bear out an ambivalent attitude towards sexual intercourse. Sexual activities were sacred and holy on one hand, but unclean and blasphemous on the other. Almost all primitive peoples held certain beliefs in the mysterious power of sexual intercourse. Such beliefs figure apparently in the ancient Chinese theory of yin and yang. The intercourse of yang and yin is held to be the essential process in the interplay of light and dark, day and night, the sun and the moon, warm and cold, male and female, sky and earth, as well as the hexagrams Qian 乾 and Kun 坤 in the Book of Changes. Guo Moruo identifies the sexual intercourse of the female and the male as the most primitive signification of yin and yang. According to Guo, the earliest diagrams for yin and yang in the Book of Changes take after primitive images of female and male sexual organs. ${ }^{57}$ The Book of Changes compares the dynamic interaction of sky and earth to the sexual intercourse of man and woman. ${ }^{58} \mathrm{Xun} \mathrm{Zi}$ recaps this sexual foundation of ancient cosmology nicely: "all beings emerge on the intercourse of sky and earth; all changes arise from the interaction of yin and yang." 59

Remarkably, the belief in the mysterious power of the intercourse of yin and yang is coupled with a system of taboos against "improper" sexual activities and social interactions between men and women. In what follows, I will present only certain typical prohibitions related directly to primitive incest taboos. The most remarkable prohibition involves the custom of exogamy: men and women with the same family name should never marry each other. The Zuozhuan warns that the marriage of men and women with the same family name would result in infertility. ${ }^{60}$ Considering the early Chinese tradition that family names were passed down along maternal lines, this ritual prohibition bears out early Chinese taboos against incest. The Baihutong identifies the origin of family name (xing 姓) as a social institution regulating marital relations and avoiding incest. ${ }^{61}$ While this prohibition was first institutionalized in Zhou dynasty, it probably stemmed from incest taboos of an earlier age.

\footnotetext{
57 Guo (2000b, p. 33): "We can see clearly that the foundation of the eight Trigrams is the relics of the ancient worship of sexual organs. Draw one line as the image of penis and divide it into two for the image of female sexual organ. From this evolved the concepts of man and woman, father and mother, yin and yang, hard and soft, heaven and earth." .

58 The Book of Changes, “Jici 繫辭:” “天地絪縕, 万物化醇; 男女构精,万物化生.” Cf. Ibid., “The alteration and communication between Yin and Yang is called the Way一陰一陽之謂道.”

59 Xun Zi 荀子, “Discourse on Li 禮論.” Cf. Liu and Yang (1992, p. 144). See also The Book of Ritual, Chapter Jiao Te Sheng 郊特牲: “The harmonious intercourse between heaven and earth results in the prosperity of all beings 天地合而後萬物兴焉.”

60 The Zuozhuan, Chapter Xi Gong the 23rd Year 僖公二十三年: “男女同姓, 其生不蕃”.

61 Chen (1994), “Xingmingpian 姓名篇”, pp. 401-419. Note that ancient Chinese people had two systems of family names: Xing 姓 and Shi 氏. Xing, which is used for women, is passed down from the maternal line and represents the blood lineage; Shi, which is used for men, is passed down from the paternal line and represents the dwelling place of one's father, and thus becomes a sign of one's nobility.
} 
Admittedly, the incest implications have turn out to be unbecoming for many contemporary scholars, who are apt to rationalize such regulations of exogamy as a form of eugenic concerns. However, dysgenesis from marriages between proximate blood lineages is no doubt a recent scientific discovery. This knowledge is unlikely to have played any significant role in early Chinese beliefs. Hence, it is more "reasonable" to attribute the origin of this taboo to the sense of guilt— to the fear or dread of disastrous punishment against the violation of primitive incest taboos. The Guo Yu states clearly that "To avoid taking a wife with the same family name is for fear of disasters." ${ }^{62}$ Here, it is relevant to recount the certain ancient beliefs and practices that are still preserved by the traditions of various ethical societies today. For example, the Chinese Wa 低 ethnic group believes that the marriage between men and women with the same family name will offend "heaven (天 tian)." It will incur punishments and disasters such as the death of human beings and domestic animals, bad crops, excessive or deficient rains and thunder strikes. ${ }^{63}$ According to Ren Cheng, many other ethnic groups hold such beliefs as well. Moreover, the prevalent ancient and indigenous fear of infertility may well have stemmed from the primitive anxiety about disastrous heavenly punishments for violation of exogamy.

This fear of punishment should be the underlying motive for a wide range of ancient and indigenous prohibitions against social interactions between men and women as well. For example, it was forbidden for family members to speak to or serve their peers of the opposite sex, including brothers and sisters, and brothers- or sisters-in-laws. Men and women who were not related were supposed to avoid each other also. They should neither sit at the same table or on the same mat, nor look at or speak to or touch each other. ${ }^{64}$ Many such regulations continue in the customs of different Chinese ethnic societies today. All these prohibitions are meant to avoid suspicious sexual involvement or temptation between men and women. ${ }^{65}$ They can all be regarded as variations of the primitive incest taboos.

In light of psychoanalysis, taboos are prohibitions against "the strongest desires of man. The desire to violate it continues in the unconscious; persons who obey the taboo have an ambivalent feeling toward what is affected by the taboo."66 As a fact, despite the strict sexual taboos, we can still discern the manifestation of strong sexual desires that were discharged through alternative outlets. One most remarkably instance for such alternative discharge may be the ceremonial spring

\section{Footnote 61 continued}

This system was later broken down so that Xing is also used for men and become a social institution for the sake of regulating the marital relationship. As Zhou Guchen elaborates, "Xing is for restricting the marriage, shi is for distinguishing the nobility... Xing is used for calling women; shi is used for calling men.... In matriarchal society, it is not woman, but man who leave his old family for marriage. Women do not leave their family for marriage, so that they are able to maintain the family name (Xing) that represents the blood lineage. During the Spring and Autumn period, matriarchal society is gone for a long time. But the customs of the use of Xing and Shi remain." (Zhou 1982, p. 4ff.).

$62 \mathrm{Xu}$ (2002, 晉語四, p. 337): “是故娶妻避其同姓, 畏亂災也.”

63 Ren Cheng, p. 91.

64 Ren Cheng, p. 77.

65 Ibid., p. 77.

66 Freud (1995, p. 802). 
revelries as recorded by the early Chinese text Zhouli: "During the second month of the spring, men and women are ordered to gather and meet each other. At that time, there is no prohibition against running/having illicit sex (bengzhebujing 奔者不 禁)." ${ }^{97}$ Remarkably, such sexual revels was not merely a temporary suspension of the sexual taboo. Rather, they were regarded as a form of ritual performance under the mandate of the government, which would "punish those who do not observe this order without a legitimate reason."68

Now the performance of such festivities, which is evidenced by a range of ancient Chinese records and narratives, ${ }^{69}$ bears out the ambivalent attitudes toward sexual and incest activities. Such incest wishes were not even completely repressed in the unconscious. Early Chinese people seemed to be well aware of the presence of such primitive impulses. As a fact, early Chinese governors often took sexual taboos as means of regulating and containing such incest wishes that were deliberately displaced and discharged through more opportune channels of fulfillments. As I will clarify further, the symbol of "dragon couples," which were widely present in the ancient Chinese artworks, provides another important means of expression for such incest desires.

\section{The sexual implications of the image of the dragon}

More often than not, the dragons appear in pairs in ancient Chinese references. Wen Yiduo alludes to more than a dozen textual sources that discourse about two dragons or a couple of dragons. ${ }^{70}$ According to Wen, the so-called jiaolong (蛟龍), which appears frequently in early texts, refers to a pair of dragons intertwined with each other having intercourse. ${ }^{71}$ As I mentioned above, Emperor Liu Bang's conception was believed to occur when a couple of dragons (jiaolong 蛟龍) had intercourse above his mother. Sima Qian's Shiji contains another legendary event featured by two dragons having intercourse in the royal court of the Xia dynasty, which was taken as a bad omen. ${ }^{72}$ Wen argues further that the so-called "two-headed serpent" and “intertwined serpent (tengshe 螣蛇)" are really two serpents mating with each other. ${ }^{73}$ Indeed, as the serpent is one of the prototypes of the dragon in early Chinese legends, the sexual implications of dragon pairs are obvious and indubitable.

Remarkably, the intercourse of dragon couples have been a recurring theme for the carvings on sacrificial instruments, jade pendants, and many other ancient artworks. The Shanghai Museum preserves a semi-annular jade pendant (yuhuang 玉璜) of late Shang dynasty, veined with two dragonheads sharing the same body. ${ }^{74}$ The Palace Museum of Taiwan preserves a bronze wine vessel (songhu 頌壸) of the

\footnotetext{
67 Zhouli Zhengyi, Chapter Di Guan Si Tu 地官司徒; Cf. Guo (2002, p. 58).

68 The Zhouli, Chapter Di Guan Si Tu 地官司徒, Cf. Guo Xingwen, p. 58.

69 See Ibid, p. 57-61.

${ }^{70}$ Wen (2001a, b, pp. 99-100).

71 Ibid., pp. 95-96.

72 Sima (1965), “Zhoubenji 周本紀."

73 Ibid., pp. 96-98.

74 See Appendix, Picture 1.
} 
late Western Zhou dynasty. ${ }^{75}$ The front of this sacrificial instrument is decorated with two dragons with the same head, their bodies entwined with each other. The Sackler Gallery of Smithsonian Institution has a bronze rice container ( $f u$ 笽) of the early Spring and Autumn period (770-476 B.C.). The body of this container is covered with the veins of interconnected dragon bodies. ${ }^{76}$ The Institute of Archaeology and Cultural Relics Bureau of Henan Province keeps a bronze cooking device ( $l i$ 鬲) of the late Spring and Autumn period. It is decorated with three dragons on the outside and covered with knotted veins representing the body of the dragons. ${ }^{77}$ Apparently, these different images of intertwined dragons all substantiate the sexual implications of dragon couples.

In my view, these images of interplaying dragon couples are not simply an art for beautiful ornamentation. Rather, they represent a common primitive belief in the spiritual power associated with sexual intercourse. The artworks of dragon couples are symbolic expressions of incest wishes and repressed desires for sacrosanct sexual energies. Artworks of this kind are too many to enumerate. Here, it suffices to mention only the most spectacular example - a bronze drum seat of the early Warring States period. Upon this drum seat are the sculptures of eight pairs of dragons tangled with each other along with dozens of smaller dragons. ${ }^{78}$ According to the interpretations of Liu Zhixiong and Yan Jinrong, this group of dragon couples represent not only sexual copulation but also reproduction. They symbolize the great spiritual endowment of sky and earth that is called Life (tiandi zhi dade yue sheng 天地之大德曰生). ${ }^{79}$

Presumably, the best evidence for the relation between the dragon and the incest wishes consists in the legends, paintings, and sculptures about $\mathrm{Fu} \mathrm{Xi}$ 伏羲 and Nü Wa 女娲, the two mythological ancestors of Chinese people. According to a variety of ancient narratives, Fu Xi and Nü Wa are not only husband and wife, but brother and sister as well. Anne Birrell identifies the evolving accounts for the marriage of $\mathrm{Fu} \mathrm{Xi}$ and Nü Wa in a wider range of literature and artworks of the Han dynasty. ${ }^{80}$ However, the mythologies of Fu Xi and Nü Wa should date back to a much earlier age. In the Warring State period, the Chu poet $\mathrm{Qu}$ Yuan already mentioned the goddess Nü $\mathrm{Wa}$ in conjunction with a divine king. ${ }^{81} \mathrm{Wang} \mathrm{Yi}$, an annotator in the Eastern Han dynasty, identifies this divine king as $\mathrm{Fu} \mathrm{Xi}^{82}$ This interpretation is supported by a silk book unearthed from an ancient tomb of the state of Chu in

\footnotetext{
75 See Appendix, Picture 2.

76 See Appendix, Picture 3.

77 See Appendix, Picture 4.

78 See Appendix, Picture 5.

79 Liu Zhixiong, p. 147.

80 Birrell 1993, p. 34: "From the period of the Former Han, the female gender of Nü Kua was underscored (some primeval gods being of indeterminate gender), and at that time she began to be paired with the mythic figure of $\mathrm{Fu} \mathrm{Hsi,} \mathrm{the} \mathrm{two} \mathrm{being} \mathrm{presented} \mathrm{as} \mathrm{a} \mathrm{married} \mathrm{couple} \mathrm{and} \mathrm{patrons} \mathrm{of} \mathrm{the}$ institutions of marriage."

81 Zhu (1979), “Tianwen 天問,” p. 63: “登立為帝, 孰道尚之. 女媧有體, 孰制匠之.”

82 Wang Yi's annotates that the first line of Qu Yuan about the divine king talks about "Fu Xi, who draws eight trigrams and cultivate virtues so that all people hold him as the king." in Jin Kaichen, A Collection of Interpretations of Question Heaven, quoted in Liu Zhixiong, p. 178.
} 
Picture 1 Semi-annular Jade Pendant with Double Dragon Heads 雙龍首人面紋玉璜. Late Shang period. Shanghai Museum, Shanghai

Picture 2 Wine Vessel for Sacrifice 頌锓. Late Western Zhou (c.1000-800 BC). Palace Museum, Taiwan

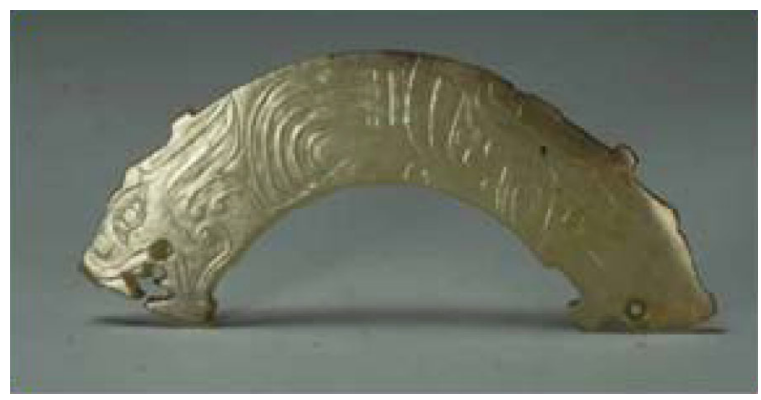

1942. In this silk book, which is held now by Freer Gallery of Asian Art, Smithsonian Institution, $\mathrm{Fu} \mathrm{Xi}$ and $\mathrm{Nü} \mathrm{Wa}$ are taken to be the divine king and queen who instigate the emergence of all beings. Their sexual copulation personifies the intercourse of yin and yang. ${ }^{83}$ The sexual symbolism of $\mathrm{Fu} \mathrm{Xi}$ and $\mathrm{Nü} \mathrm{Wa}$ is highlighted in a wide range of paintings and sculptures that typically portray them as a man and a woman with serpent-like bodies, whose tails are closely intertwined with each other.

I have mentioned above certain early legends that relate the conception of the divine king $\mathrm{Fu} \mathrm{Xi}$ to the Lake of Thunder, which carries symbolic implications of the dragon. As a fact, the serpent has long been a prototype of the dragon in early Chinese folklore. It is thus reasonable to conclude that the serpent bodies of $\mathrm{Fu} \mathrm{Xi}$ and Nü Wa symbolize really two dragons intertwined with each other having intercourse. The images of $\mathrm{Fu} \mathrm{Xi}$ and Nü Wa constitute an artistic symbolism for

${ }^{83}$ Lian (1991, pp. 40-46). Cf. Liu Zhixiong, p.179ff. 


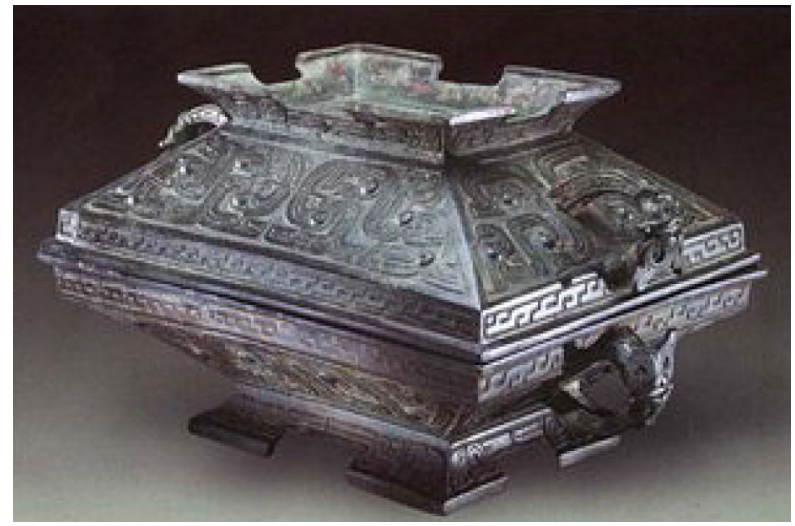

Picture 3 Rice Container With Veins of Entwined Dragon 交龍紋笽. Eastern Zhou, Early Spring and Autumn period. Height $21.5 \mathrm{~cm}$; Length at Lip $37.5 \mathrm{~cm}$. Sackler Gallery. Smithsonian Institution, Washington, DC

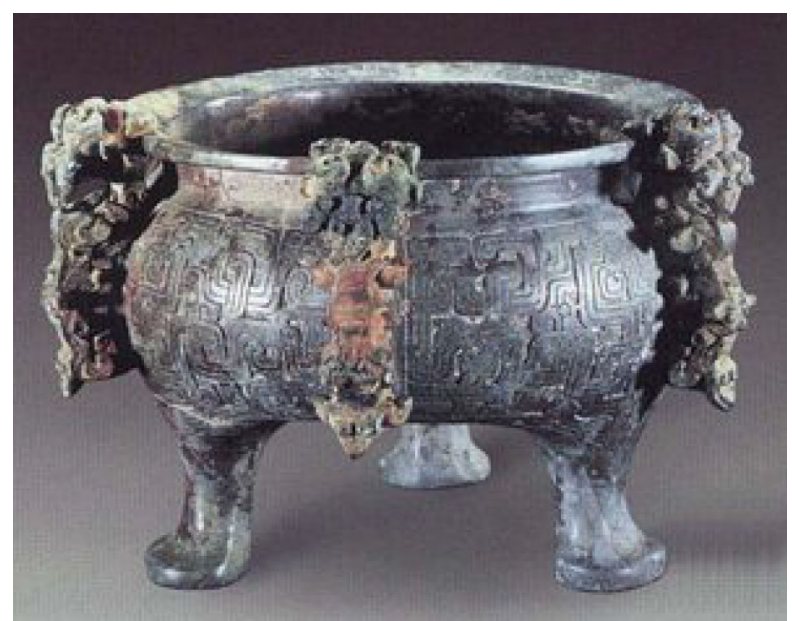

Picture 4 Cooking Device with Veins of Entwined Dragon交龍紋鬲. Late Spring and Autumn period. Height $12.6 \mathrm{~cm}$; diameter $15.5 \mathrm{~cm}$; Excavated in 1978 at Zhechuan, Henan Province. Institute of Archaeology and Cultural Relics Bureau, Henan province

Picture 5 Drum Seat with the Sculpture of the Dragons in the Second Tomb of the Duke of Zeng 曾侯乙透雕龍紋鼓座. Eastern Zhou, Early Warring States period. Height $54 \mathrm{~cm}$, diameter $80 \mathrm{~cm}$, weight $192.1 \mathrm{~kg}$. Excavated in 1978 at no. 1 tomb, Leigudun, Sui district, Hubei province. Hubei Province Museum, Wuhan

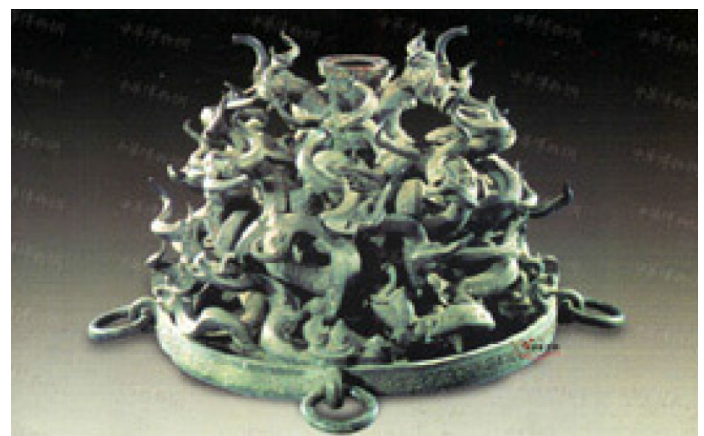


the primordial sexual and incest desires. Curiously, compared with the Greek Oedipal myth that highlights the sexual relationship between mother and son, Chinese mythology tends to emphasize the incest relationship between brother and sister. As a fact, this motive of brother-sister incest relationship is present again in the mythological traditions of a range of contemporary Chinese ethnic societies. In almost all these ethnic groups, there have been certain old legends that identify the ancestors of human beings as a brother and a sister who were compelled to marry each other after a disastrous flood. Wen Yiduo identifies twenty-five distinctive records of these legends. He shows that the heroes and heroines in a good portion of these stories are either identified as $\mathrm{Fu} \mathrm{Xi}$ and $\mathrm{Nü} \mathrm{Wa}$ or found to have very similar names. ${ }^{84}$

\section{The myths of Oedipus and the dragon: unity and limitation of the psychoanalytic interpretation}

I have demonstrated that the two aspects of the Oedipus complex-the father complex and the incest wish-can both find their counterparts in early Chinese dragon worship. As the conclusion of this study, I will now lay bare how these two psychological syndromes can be resolved or at least contained with the institution of the super-ego or ego-ideal. In so doing, I hope to provide a coherent interpretation of the psychological complexes underlying early Chinese dragon worship. At the same time, I will also note some basic differences between the Chinese and Greek mythological traditions, as well as certain limitations of the psychoanalytic interpretation.

For Freud, the fundamental condition underlying the Oedipus complex is "the lengthy duration in man of his childhood helplessness and dependence." ${ }^{\circ 5}$ This helpless situation begins with the "great anxiety-state of birth and the infantile anxiety of longing - the anxiety due to separation from the protecting mother." 86 Freud takes this childhood helplessness as a fundamental biological factor accountable for the development of the Oedipus complex and the genesis of the super-ego. The formation of the super-ego is a collective coping mechanism to manage such common traumatic situation.

In sum, there have been two typical mechanisms to deal with the primal anxiety about the traumatic situation of helplessness: (1) the recourse to the pleasure of sexual intercourse, which is imbued with mysterious power in various animistic beliefs. According to the early Chinese tradition, this mysterious power of sexuality is symbolized by the forces of yin and yang vital for the life of all beings; (2) the establishment of an ego ideal or super-ego as the protector and guarantor, which is most vividly embodied in the supreme godly figure in primitive ancestor worships. Apparently, these two ways of coping with the primal anxiety correspond to the two aspects of the Oedipus complex. We can have a more penetrative understanding of

\footnotetext{
${ }^{84}$ Wen (2001a,b, pp. 86-91).

85 Freud, The Ego and the Id, pp. 30-31.

${ }^{86}$ Ibid., p. 61.
} 
these two aspects of the Oedipus complex by laying bare the significance of the mysterious power essential for both the authority of the father and the charm of sexuality.

As I have clarified above, early Chinese images and legends of intertwined dragons provide an important channel for the symbolic satisfaction of sexual and incest wishes. Here, it is relevant to note further the animistic belief in the spiritual power of sexuality, which is symbolized by the totem of the dragon. The belief in the mysterious power of dragon couples was key to early Chinese rain magic and ceremonies. As Wang Chong interprets, the basic motive of rain ceremony is to harmonize yin and yang so that rain will come of itself. ${ }^{87}$ But how can one ensure the harmonious intercourse of yin and yang? Early Chinese people, like many other ancient peoples, adopt the magic of imitation. They expect to elicit rain by regulating and harmonizing their own sexual relations, and by producing the harmonious interplay of dragon couples in various artistic and ritual representations. ${ }^{88}$

In my view, the clarification on the significance of this mysterious spiritual power - the so-called mana potency associated with sexual intercourse can bring a coherent interpretation on the two aspects of the Oedipus complex in early Chinese dragon worship. Now this mana potency is essential for both the charm of sexuality and the authority of the father and the king. As Freud clarifies, the father and the king are "the bearer of that mysterious and dangerous magic power which communicate itself by contact, like an electric charge, bringing death and destruction to any one not protected by a similar charge." 89 I have demonstrated already the early Chinese beliefs in this mysterious spiritual power that is responsible for the birth of the great kings and emperors. According to these early myths and legends, the conceptions of the great father figures were only possible when the spiritual power symbolized by the dragons enters the wombs of their mothers.

Remarkably, with the possession of this exclusive spiritual power, the father is elevated as the personification of the super-ego or the ego-ideal. According to psychoanalysis, the formation of the ego ideal or super-ego depends also or even more on the sanctified identity of social and political authority than on the real father. ${ }^{90}$ As I see it, it is the psychological image of "the father"-as incarnated in the person of the king or the ancestor-who are accredited with the godly authority with mysterious power. Freud clarifies that a child's super-ego "is in fact constructed on the model not of its parents but of its parents' super-ego." "91 Thus, the formation of the super-ego of an individual in a contemporary society would involve

\footnotetext{
87 Wang (1965, Chapter Luan Long 亂龍, Cf. Liu Zhixiong, p. 251).

${ }^{88}$ For more detailed description of the ceremony for rain and its relation to the dragon, see Su (1992), “Qiuyu 求雨," pp. 426-436; Cf. Liu Zhixiong, pp. 248-251ff.

89 Freud (1995, p. 807).

90 Cf. Freud (1960, p. 33): "As a child grows up, the role of the father is carried on by teachers and other authority; their injunctions and prohibitions remain powerful in the ego ideal and continue in the form of conscience, to exercise the moral censorship."

91 Freud (1965, p. 67).
} 
the repetition of certain historical developments of the super-ego as instituted in primitive totemism.

In sum, the ambivalent attitudes toward both the father and sexual wishes originate in the ambivalence toward the mysterious spiritual power essential for the vitality of all beings. The prerogative of "the father" consists precisely in his exclusive control over such mysterious power. This prerogative ensures the sexual privilege of the real father over the mother. To a great extent, it is the father's monopoly of sexual pleasure that incites increasing envy and hostility of the sons. With their growing sexual wishes toward the mother and sisters, the sons' love of the father clashes desperately with their hostility toward the father. As I have clarified above, this ambivalent feelings toward the father stems from the paradoxical human situation characterized by the infantile helplessness. This helpless human situation is epitomized by the double attitude toward the vital spiritual power: which one desires to control but dare not take (full) possession. At a result, one has to repress and give up the instinctive desire for fear of the destructive power of the mana potency.

Psychologically, the repression takes place when the need for a protecting father prevails over the desires for the power and pleasure of sexuality. In the end, these instinctual drives, including the hostile feelings toward the father and sexual wishes for the mother and sisters, must be displaced and projected upon substitutive objects. For early Chinese people, the dragon becomes the symbol upon which both the hostility toward "the father" and the incest wishes are projected and displaced. We can regard the dragon totem as the substitute for the deceased father upon which the fear of its demonic figure finds its primary incarnation.

Now the demonic nature of the dragon is common for the images and legends about the dragon in both the East and West. Such primitive demonization of the father relates well to the tension and confrontation between the father and the son as highlighted in the Greek tragedy of Oedipus. But how and why does the dragon become a primarily benevolent figure in traditional Chinese culture? In my view, this intricate question implicates the distinctive style of particular cultural development that cannot be explained forthright by resorting to any universal theories of humanity. Though psychoanalysis is revealing about the fundamental psychological complexes common for all cultures and societies, it nonetheless has its limitation in providing satisfactory explanations on why a cultural tradition come up with its particular solutions for these common problems.

As I see it, the transformation of the dragon from a demonic creature into an auspicious animal marked a metaphorical reconciliation of the ambivalent feelings toward the father. The institution of the dragon as the clan totem comes about as early Chinese people endeavor to "balance" their sexual desires with their love and care for the protective father. This tension between hostility and love reaches a reconciliation when all members of the society are able to identify themselves with the dragon-a symbolic substitution of the father. This reconciliation is facilitated by the double symbolism of the dragon: which represents the authority of the father and the charm of sexuality at the same time. The combination of these two psychological motives in the single image of the dragon induces a vicarious satisfaction of the sexual instincts under the protection and authorization of "the 
father." This mediated satisfaction obtains when all individual members of the society identify themselves with the totem of the dragon as they submit to the authority of the father and the taboos safeguarding his sacrosanct power.

Overall, the Chinese totem of the dragon and the Greek myth of Oedipus mark two different approaches toward the primordial human destiny that is characterized by paradoxical traumatism. Sophocles' tragedy of Oedipus epitomizes the heroic encounter with the inescapable human destiny. It highlights a sublime form of Greek mentality informed by the irreconcilable tension between the universal and the particular, the father and the son, the sacrosanct power of the society and the free desires of the individual. In contrast, the Chinese demonstrate an inclination for cunning circumvention of such tragic encounters. From the Chinese perspective, the root of all tension and confrontation lies in the instinctual insistence on the idea and identity of the ego. Accordingly, the key to overcome such tragic and traumatic destiny of humanity boils down to an art of self-cultivation: an art to temper and release the self from the instinctual insistence on its own narcissistic sanctity.

Thus, the prevalence of the benevolent nature of the dragon bear out precisely the central importance of benevolence (ren 仁) for the early Chinese civilization. In a recent study, I have demonstrated the true and original meaning of the Confucian idea of ren as the empathic openness of the self. ${ }^{92}$ Accordingly, we can regard the essence of the Confucian self-cultivation as a process of person opening. The ideal of moral education is to promote gradually the readiness and resilience of a person to harmonize its desires and intentions with the dynamic conditions and directives in the surrounding world. Indeed, in contrast with the supreme and sacrosanct power of law and authority highlighted in the Greek order of justice, the central mission of the Confucian order of ritual is the general cultivation of open-minded and benevolent personalities. The foundation of early Chinese political order hinges on the appropriate and benevolent dissemination of the vital cosmic vibrancy for every member of the society so that all people would live up to their family and social responsibilities without selfish misappropriations. ${ }^{93}$ Arguably, this Chinese ideal of cosmic and political order, which is presaged in the benevolent nature of the dragon and its protean identities, promises a way of human development that is more open, flexible, and enlightening than the prevalent Western ideal of civilization pivoting on the universal authority of law and the rights of competing egocentric identities.

\section{Appendix: Artworks with dragon images}

See Pictures 1, 2, 3, 4 and 5.

\footnotetext{
92 See Wang (2012) for a demonstration on the most original meaning of ren as gantong, namely "empathetic openness."

93 See Wang (2015) for an interpretation on this early Chinese political order based on the harmonious circulation of cosmic vibrancy and poetical correspondence of sky, earth and the humankind.
} 


\section{References}

Ban, G. 班固. (1965). Hanshu/History of Han漢書. in Si Bu Bei Yao.

Birrell, A. (1993). Chinese mythology: An introduction. Baltimore: The Johns Hopkins University Press. The Book of Ritual/Liji with Zheng Commentary禮記鄭注. (1965). In Si Bu Bei Yao.

Chen, L. 陳立. (Ed.) (1994). Annotations on the Baihutong 白虎通疏證. Beijing: Zhonghua Shuju.

De Visser, M. W. (1913). Dragon in China and Japan. Amsterdam: Johannes Müller.

Freud, S. (1960). The ego and the id (J. Riviere, Tans.). New York: W.W. Norton \& Company.

Freud, S. (1965). New introductory lectures on psychoanalysis (J. Strachey (Ed.), Trans.). New York: W. W. Norton \& Company, Inc.

Freud, S. (1995). Totem and Taboo. In The basic writings of Sigmund Freud (A. A. Brill (Ed.), Trans.) (pp. 775-898). New York: The Modern Library, 1995.

Guo, M. 郭沫若. (2000a). The development of the concept of the way of heaven in Pre-Qin China 先秦天 道觀之進展.” In The Bronze Age 青銅時代, Vol. 1 of Investigations of Ancient Chinese Society 中 國古代社會研究 (pp. 303-360). Shi Jiazhuang: He Bei Education Press.

Guo, M. (2000b). The social life in the age of the Book of Changes周易時代的社會生活.” In Investigation of Ancient Chinese Society中國古代社會研究, Vol. I of Investigation of Ancient Chinese Society中國古代社會研究 (pp. 32-86). Shi Jiazhuang: He Bei Education Press.

Guo, X. 郭興文. (2002). Traditional marriage customs in China 中國傳统婚姻風俗. Xi An西安: Shan Xi People's Press陕西人民出版社.

Hanfeizi. 韓非子. (1965). in Si Bu Bei Yao.

Ji, C. 吉成名. (2002). The customs of dragon worship in China 中國崇龍習俗. Tianjin: Tianjin Classics Publishing House.

Keightley, D. N. (2004). The making of the ancestors: Late Shang Religion and its legacy. In J. Lagerwey (Ed.), Religion and Chinese Society. Ancient and Medieval China, Vol. I. Hong Kong: The Chinese University Press.

Lévi-Strauss, C. (1963). Totemism (R. Needham, Trans.). Boston: Beacon Press.

Lian, S. 连劭名. (1991). The silk books of the State of Chu found in Changsha and the Ancient Chinese Cosmology长沙楚帛书与中国古代的宇宙论. Wen Wu文物, 2, 40-46.

Lin, Y.林尹, \& Gao, M 高明. (1985). The Encyclopedic Dictionary of the Chinese Language 中文大辭典. $7^{\text {th }}$ ed., 10 Vols. Ed.. Taibei: Chinese Culture University Press.

Liu, Z. 劉志雄, \& Yang, J. 楊静荣. (1992). The Dragon and Chinese Culture龍与中國文化. Beijing: People's Press.

Piddington, R. (1952). An introduction to social anthropology (Vol. I). London: Oliver and Boyd.

Rawson, J. (Ed.). (1996). Mysteries of Ancient China: New discoveries from the early dynasities. New York: George Braziller.

Ren, C. 任骋. (2004). Popular taboos in China 中國民間禁忌. Beijing: China Social Sciences Press.

Si Bu Bei Yao. (1965). The complete selection of the most important works in the four categories of Chinese classics 四部備要. Taibei: Zhonghua Shuju.

Sima, Q. 司馬遷. (1965). The Shiji/history史記. in Si Bu Bei Yao.

Smith, E. (1919). The evolution of the dragon. Manchester: The University Press.

Smith, D. H. (1968). Chinese religion. New York: Holt, Rinehart and Winston.

Su, Y. 蘇輿. (1992). Chunqiu fanlu yizheng春秋繁露義證 (Expositions on Fanlu and other Treatises on the Spring and Autumn Annals). Beijing: Zhonghua Shuju.

"Totemism". (Ed.) (2015). Joseph Haekel. Encyclopcedia Britannica. Encyclopcedia Britannica Online. Encyclopædia Britannica Inc., 2015. Web. 28 Jun. 2015. http://www.britannica.com/topic/totemismreligion.

Tu, E. 杜爾未. (1967). The four divine animals-Phoenix, Unicorn, Tortoise and Dragon 鳳麟龜龍考釋, 2nd. ed. Taiwan: The Commercial Press, Ltd.

Wallace, E. R., IV. (1983). Freud and Anthropology: A History and Reappraisal, Monograph 55. Psychological Issues. New York: International Universities Press, Inc.

Wang, C. 王充. (1965). Lung Hen論衡. In Si Bu Bei Yao.

Wang, H. (2012). Ren and Gantong: Openness of heart and root of confucianism. Philosophy East and West, 62(4), 463-504.

Wang, H. (2015). A genealogical study of De: Poetical correspondence of sky, earth, and humankind in the early Chinese Rule of Benefaction. Philosophy East and West, 65(1), 81-124. 
Wen, Y. 闻一多. (2001a). A study of Fu Xi伏羲考.” In Dead Water, Myth, and Poetry死水, 神话与诗. Guiyang: Gui Zhou Education Publishing House.

Wen, Y. (2001b). Study on the story of Jiang Yuan's treading on the footprint of a great man 姜嫄履大人 迹考.” In Dead water, myth and poetry 死水, 神话与诗. Guiyang: Gui Zhou Education Publishing House.

Williams, C. A. S. (1976). Outlines of Chinese symbolism and art motives (3rd ed.). New York: Dover Publication Inc.

$\mathrm{Xu}, \mathrm{Y}$. 徐元誥. (2002). Collected annotations of the Guoyu 國語集解. Beijing: Zhonghua Shuju.

Yuan, K. 袁珂. (2003). Myths in ancient China 中國古代神话. Beijing: Hua Xia Press.

Zhou, G. 周谷城. (1982). History of politics in China中國政治史. Beijing: Zhong Hua Shuju.

Zhouli Zhengyi. 周禮正義. (1965). In Si Bu Bei Yao.

Zhouyi/The Book of Changes. 周易. (1965). In Si Bu Bei Yao.

Zhu, X. 朱喜. (1979). Collected Annotations on the Chuci楚辭集注. Shanghai: Shanghai Guji Chubanshe.

Zuozhuan. 左傳. (1965). In Si Bu Bei Yao. 